\title{
The Justice of Higher Education: a Necessary Care of Education
}

\author{
Fu Jinlan ${ }^{1}$ An Hongtao ${ }^{2}$ \\ Zaozhuang University, zaozhuang,Shandong Province 277160, China \\ Zaozhuang University, zaozhuang,Shandong Province 277160, China \\ zaozhuang,Shandong Province 277160, China \\ email: ghj7507@126.com
}

\begin{abstract}
It is an ethical requirement that realizing everyone's equal right to accept education is an important aspect to realize social equality. Aimed at the conflicts between higher education opportunities and the demands of higher education, the paper elaborates these real problems in detail. Through empirical research and document retrieval methods, the paper offers a series of recommendations, such as higher education resources sharing policies, appropriate inclination to make up disadvantaged groups, and attach importance to education legislation and institutional innovation. In summary community should ensure that everyone has equal education opportunities to obtain higher learning. Therefore it is urgent to develop and utilize the existing resources of higher education.
\end{abstract}

Keywords: education justice; higher education; disadvantaged groups; education resources sharing policies; education legislation

\section{Introduction}

Educational justice is a beautiful pursuit of harmonious society which is the basis of social justice. The right to be educated should be equally enjoyed by every citizen. So realizing everyone's equal right to accept education is an important aspect to realize social equality. Further more it is an ethical requirement. But the limitation of higher education' opportunities made the contradictions more acute between educational opportunities and the number of requirements. So the opportunities distribution of higher education has risen to an important position. Further more, the real situation is often that who can enjoy the good education, who would gain more opportunities and space to develop himself. Then the inequality of starting point will inevitably lead to the inequality of development process and development results. Aristotle pointed out, "A city in the education system must be for all citizens, and it is its duty to plan the system." Hence higher education should remain the most fundamental principles of justice; otherwise it will become the booster of social inequality. So the implement of justice of higher education is a necessary education concern.

\section{Main text}

\subsection{The Connotation of Education Justice}

Justice is human society's basic philosophy and basic rules with eternal value. From John Rawls' 
expression "as a fair justice", we can see the domain justice is much wider. It involves the basic system of society, as well as the social members' basic behavioral value orientation. Justice has social preference, and it needs the guarantee of social system. So we can say that only with the principles of justice system can we ensure true impartiality. In short, justice is associated with certain social fundamental systems, and with this the criteria it provisions the members' specific rights and the obligations, the proper arrangement and rational distribution of resources and interests between the social groups and the social members.

Therefore, educational justice means that everyone should enjoy equal education opportunities to make their own potential to a better development. Every citizen may create an ideal "self" by studying and achieve the rights of pursuit of self-worth and self-realization. When the learners are in constant pursuit of these inherent requirements, his potential in this process will be set free, which means he will win his self-realization. And the self-realization is a right that society should give everyone. Furthermore any fair society should be in unremitting efforts to realize the individual rights' equal implement.

\subsection{The Implement of Justice of Higher Education Is a Necessary Education Concern}

Society should not make any group or individual be discriminated in gaining learning opportunity for any reason. The opportunity that everyone receives higher quality education should be equal. If a community can't satisfy people's equal education needs, it can't form and develop its ability. Whatever the causes are, it will be unfair or unjust. Those who didn't get an education opportunity. The factors are manifold, but social delinquencies in justice make them become inadequate in every respect even entirely deficient in preparation. This leads the "inferior" to even more disadvantageous position, and "stronger" to a more dominant position, thus social inequality will become much more prominent.

Equal concern and respect require that no one should receive bad treatment for the different of environment and the responsibility difference. The achievements and gains would be different because his personal life planning is different. From personal development perspective, if the scope of the equality is growing, perhaps we can improve the existing conditions as a whole. Further more the unequal result is not only bringing about effect to the poor, but also it will make society pay more cost to repair the damage by poverty. In fact, if we consider the relations among people, the more equality, and the more social cohesion and the higher fusion will be created.

Everyone in fulfilling the ideal way of life should be treated equally. According to the universal declaration of human rights, whether be accepted by higher education institutions should be based on the performance, ability, and level of effort, perseverance and dedication. Everyone should be eligible to receive higher education regardless of race, gender, language, religion, or cultural, social status etc. Certainly equal concern and respect do not simply mean giving everyone the same treatment, despite the differences between people. Otherwise it means everyone should be treated as subject-of-life. Everyone has the right to go to university, but it doesn't mean that everybody has this right. Higher education in achieving social fairness is becoming more and more important. Education is an instrument, through this means that people despite of their genetic background can receive social benefits. Then they can be more welcome and be absorbed into society, but not be refused by the community.

\subsection{The Gradual Realization of Higher Education Justice}

Higher education justice need necessary policy supports. Higher education developmental 
disequilibrium has its own historical, economic, cultural reasons, and has the effect of policy leading direction. So we must emphasize the government's responsibility. When the government provides education and public goods, the government should formulate a scientific and reasonable policy to regard educational justice as the most important target.

\subsubsection{The Implementation of Higher Education Resources Sharing Policies}

The government in promoting the process of education justice plays an important role. We should face the historical, geographical or other cause of education's being unfairness. Reasonable allocation of public education resources can meet the most disadvantageous' greatest advantage. The government should put more educational resources to those who are at a disadvantageous condition. Then they can bridge the gap.

With the informatization of high development, higher education's social needs are augmenting daily. But the public education expenditure has been inadequate to meet the demand. So the conflict between making higher education popularize or be universal and the deficiency of government financial input becomes a global issue. Resources are always rare. But in using rare resources, the use of resources should come to optimal efficiency which is called real justice. So it is necessary to implement the higher education sharing resources policies and break higher education resources boundaries. Through the union and integration of schools, the education resources can be shared among different schools. Modern education is an open social system. In the resource supply or configuration, besides the government's public education resources, other channels can also provide education resources.

Meanwhile with the application of Internet media and information technology and the development of modern science and technology, the bar of education space is relieved, which means higher education resources can be shared in the different space. Therefore, developing long-distance education and internet education can promote the development of backward areas through informatization, which will make superior quality of education resources share in the undeveloped areas and the backward areas, and narrow "information gap".

\subsubsection{Appropriate Inclination to Make Up Disadvantaged Groups}

In the interests of the diversity, the problem of interests expressing, particularly the problem of vulnerable groups' interests is an unavoidable. The starting point of disadvantaged groups is at a disadvantage, so they should be given special attention. The realization of social justice should make the population of the worst living conditions as a basis and premise. Otherwise people's basic rights will not be able to be realized. As Plato thought, justice is the whole members' advantage, and justice is real harmonious social order. For social development encompasses people's development, it is impossible to overlook the existence of the minority or the weak. Although the vulnerable groups in some respects are at a disadvantage, but their knowledge and actions are indispensable to social development. Only by giving a necessary precondition to this class can be conducive to the healthy development of society. Social justice is immeasurable for vulnerable groups to change their fate.

The policies of protecting vulnerable groups should not only have its theoretical and legal basis, but also become a bounden duty that government and the dominant group should assume. As John Rawls pointed out, these anticipants partly depend on the economic and social environment, also depend on political system. Thus, the social system may benefit to some starting points against others. This is the profound inequalities. This inequality is ubiquitous, it will also affect the life of 
the final opportunity; And in any social basic structure, this inequality is probably unavoidable, and social justice principle must first be applied to unequal phenomena. Rawls' thought embodies the care to the most unfavorable groups and gives us appropriate theoretical basis on how to treat education justice. Only by continuously improving the education system of facing all the members can the vulnerable strata gain the basic rights and can the government gain understanding and support of vulnerable strata. Therefore the whole community can be in a relatively harmonious balance.

\subsubsection{Importance to Education Legislation and Institutional Innovation}

In the course of pursuit of educational justice, it is of vital importance to take into account of education legislation. Everyone has equal rights to receive an education. In the early 20th century, the right to receive education as a statutory right and inalienable personal rights was written into various countries' constitution successively, which negated the education rights of privilege and guaranteed the equal rights of education. In1948 the universal declaration of human rights regarded the ability to read and write as one of the basic human rights, as a tool of modern life. And only by social support system, can education as one of the basic rights be truly achieved. So the legislation is most effective to life-long guarantee.

To be frankly speaking, only the right to learn is acknowledged in law and institute, will it be guaranteed. And only society ensure everyone's learning right can it constantly contribute to people's full development, and ultimately promote social progress and development. We have to concern all the people in the context for a genius. Therefore, according to one's different circumstances, for those whose situation are worse than most men, those adults who have lost access to higher education opportunities, or those because of seeking employment or the needs of the changing work or enriching himself life, universities should provide them relaxed conditions to meet the needs. Society should be sure that everyone has equal education opportunities to make those who are unable to obtain higher learning to have a chance to return to learn.

\section{Conclusions}

Community should ensure that everyone has equal education opportunities to obtain higher learning. Therefore it is urgent to develop and utilize the existing resources of higher education. The government should be in financial support to provide in-service training opportunities and time for study. Meanwhile the government should be responsible to ensure that everyone can continue to study and admit their formal acceptance of technical and vocational education. Higher education popularization is a process, and new unfairness will come in pursuit of justice, so to achieve a higher education need a long time.

\section{References:}

[1] Aristotle. Politics. Wu Shoupeng. Bejing: Shangwu Publishing House, 1983.406

[2] Michael walzer. Spheres of Justice. Ch songyan. Nanjing: Yilin Press, 2002.269

[3] UNESCO. The Hot Research areas of Global Education Development. Zhao Zhongjian. Beijing: Educational Science Publishing Housing, 1999.416

[4] John Rawls. A Theory of Justice. Xie Yanguang. Shanghai: Shanghai Yiwen House, 1991.107 
[5] John S Brubacher. Higher Education Philosophy. Wang Chengxu. Hangzhou: Hangzhou Education Press, 2002.74

[6] LI Gai-hu,YANG Gui-lan. The Historical Process Analysis of China's Higher Vocational Education Policy in the Three Decades of Reform and Opening.Journal of Hunan Industry Polytechnic,2010-02

[7] ZHAN Chun-yan, Quality Risk Management in Our Higher Education, Journal of South China Normal University(Social Science Edition),2008-02

[8]Apple, M.(Ed.)(2009).Global crises, social justice, and education. New York: Routledge.

[9]Carnoy, M.(1999). Globalization and educational reform: hat planners need to know. Paris: UNESCO, International Institute for Education Planning.

[10] LIU Yuan, The Practice of British Vocational Qualification Assessment System and its Enlightenments to China, Journal of Hebei Polytechnic College,2007-02 